\title{
RELASI BAHASA DAN IDEOLOGI
}

\author{
Ahmad Mubaligh
}

\author{
Email: abaelma@gmail.com \\ Jurusan Bahasa dan Sastra Fakultas Humiora dan Budaya UIN Malang \\ Alamat Korepondensi: Jalan Joyo Suko Gg. Metro II/45 Malang
}

\begin{abstract}
Language is an arbitrary code system having close relationship with the ideology, because in any use of the language is ideological. According to linguists language is ideology. The relationship between language and ideology is in its language use and materializing the language in ideology. Words used and the meaning coming up from the words show someone's position in a certain social class. Language becomes a battle site for many groups and class who take great effort to instill its belief and perceiving. In addition, the relationship of language and ideology can also be seen from its use not only as a means of communication but also language as a tool to influence, change and dominate other people so that the reader or audience will receive and justify the messages, ideas, and thought delivered, even to believe and follow it.
\end{abstract}

\section{Keywords}

Bahasa, Ideologi

\section{Pendahuluan}

Bahasa merupakan salah satu bagian terpenting dalam kehidupan manusia karena setiap manusia dalam berbagai aktivitas dan kehidupannya selalu berhubungan yang erat dengan bahasa. Dalam berkomunikasi dan bersosialisasi dengan lingkungan, manusia menggunakan bahasa dalam mengungkapkan totalitas pikirannya. Bagitu pula dalam berbagai aspek lain, manusia juga menggunakan bahasa. Pendek kata, tidak seorangpun dalam hidupnya yang bisa lepas dari bahasa.

Menurut Mudjia Rahardjo (2002:iii) bahasa dan manusia menyatu dalam segala aktivitas kehidupan. Di mana ada manusia, di sana ada bahasa. Pun juga sebaliknya, keduanya tidak bisa dipisahkan. Bahasa tumbuh dan berkembang karena manusia. Manusia dapat berkembang karena bahasa. Bahasa pula yang membedakan manusia dari makhluk ciptaan Tuhan yang lain. Bahasa menentukan identitas atau jati diri manusia, baik secara individu maupun kelompok masyarakat.

Bahasa, menurut Hidayat (2006: 263-264), adalah sine qua non, sesuatu yang mesti ada bagi kebudayaan dan manusia. Dengan bahasa, manusia mampu mengabstraksikan seluruh pengalaman empiris, rasional, dan spiritualnya secara konseptual, sistematis, dan terstruktur yang pada gilirannya dapat melewati sekat-sekat ruang dan waktu. Dengan bahasa, manusia sanggup memasuki dunia lain yang jauh lebih luas dan kompleks. Dengan bahasa, manusia dapat pula menyampaikan dan mengembangkan pemikirannya dalam aneka wujud kebudayaan. Bahkan lebih dari itu, dengan bahasa manusia dapat mempengaruhi dan mendominasi orang lain, baik dalam sikap maupun pikirannya.

Kemudian, seiring dengan dinamika kehidupan manusia, bahasa telah menjadi sebuah dilematis dan mengalami perubahan makna dan fungsi yang luar biasa. Bahasa yang dahulunya hanya digunakan sebagai alat komunikasi, kini sudah bergeser pada kepentingan, dominasi, budaya, kekuasan dan lain sebagainya. Bahasa telah berubah menjadi suatu legitimasi tentang bagaimana seseorang mampu menguasai orang lain dan bagaimana orang lain bisa mengikutinya. Lebih-lebih setelah muncul wacana postmodernisme dan post-strukturalisme yang turut berperan dalam perubahan dan pergeseran fungsi bahasa tersebut.

Derrida, salah seorang tokoh post-modernisme, mengatakan bahwa bahasa bukan sekadar urutan-urutan kata yang diatur oleh tata bahasa dan dan dipilih secara bebas oleh penuturnya, tetapi bahasa adalah manifestasi totalitas pikiran manusia yang terikat dengan kondisi, setting, dan maksud yang hendak disampaikannya, serta target yang akan diraih. Ide ini terus berkembang tergantung pada siapa yang mengucapkannya. 
Makna "kata", lantas bukan hanya dibawah oleh kata itu sendiri, tetapi oleh siapa, di mana, kepada siap dan kapan kata itu diucapkan (Rahardjo, 2002: v).

Berpijak dari pemikiran tersebut, penulis ingin menjelaskan tentang relasi antara bahasa dan ideologi, yang meliputi tiga pokok bahasan, yaitu teori tentang ideologi, hakikat dan fungsi bahasa, serta relasi bahasa dan ideologi.

\section{Teori tentang Ideologi}

Secara etimologis, kata ideologi berasal dari bahasa Greek yang terdiri atas kata idea dan logia. Idea berasal dari idein yang berarti melihat. Idea dalam Webster's New Calligate Dictionary berarti "someting existing in the mind as the result of the formulation of an opinion, a plan or the like" (sesuatu yang ada di dalam pikiran sebagai hasil perumusan sesuatu pemikiran atau rencana). Sedangkan logis berasal dari kata logos yang berarti word. Kata ini berasal dari legein yang berarti to speak (berbicara), logia berarti science (pengetahuan) atau teori (Sobur, 2004:64).

Secara terminologis, istilah ideologi didefinisikan oleh banyak kalangan secara berbeda-beda. Dalam pengertian yang paling umum dan lunak, ideologi adalah pikiran yang terorganisir, yakni nilai, orientasi, dan kecenderungan yang saling melengkapi sehingga membentuk perspektifperspektif ide yang diungkapkan melalui komunikasi dengan media teknologi dan komunikasi antar pribadi (Sobur, 2004:64).

Penggunaan istilah ideologi tersebut, menurut Jhon B. Thompson (1984:17), memiliki sejarah panjang dan kompleks yang tampak dalam karya beberapa penulis dan merambah ke beberapa disiplin modern dalam ilmu-ilmu sosial dan humaniora. Menurutnya, jika diteliti dengan cermat, istilah ideologi digunakan dalam dua cara yang berbeda. Pada satu sisi, ideologi digunakan oleh beberapa penulis sebagai sebuah istilah yang murni deskriptif; sebagai sistem berpikir, sistem kepercayaan, praktik-praktik simbolik yang berhubungan dengan tindakan sosial dan politik. Penggunaan istilah ini telah memunculkan apa yang disebut dengan konsepsi netral (neutral conception). Pada basis konsepsi ini, tidak ada upaya untuk memisahkan antara jenis-jenis tindakan dengan animasi ideologi; ideologi hadir dalam setiap program politik, mengabaikan program yang dimaksudkan sebagai pemeliharaan dan transformasi sosial. Namun pada sisi lain, ideologi juga digunakan oleh beberapa penulis yang secara mendasar mempunyai hubungan dengan proses pembenaran hubungan kekuasaan yang tidak simetris, berhubungan dengan proses pembenaran dominasi. Penggunaan istilah yang demikian menunjukkan apa yang disebut dengan konsepsi kritis ideologis (critical conception of ideological). Penggunaan ini mengandung konotasi negatif dan akan selalu mengikat analisa ideologi pada pertanyaan kritis.

Berbeda dengan pandangan Thompson, Raymond William mengklasifikasikan penggunaan ideologi dalam tiga ranah. Pertama, sebuah sistem kepercayaan yang dimiliki oleh kelompok dan kelas tertentu. Ideologi di sini adalah orientasi tindakan (action-oriented) yang berisi kepercayaan yang diorganisir dalam suatu sistem yang koheren. Ia adalah kumpulan kepercayaan dan ketidakpercayaan (penolakan) yang diekspresikan dalam kalimat-kalimat yang bernilai permohonan, dan pernyataan eksplanatoris. Dalam konteks ini, ia terbagi ke dalam ideologi fundamental dan ideologi operatif. Ideologi fundamental ialah prinsip fundamental yang meyakini tujuan akhir dan pandangan besar yang akan dicapai. Ideologi operatif adalah prinsip-prinsip yang secara aktual mendasari kebijakan yang dimaksudkan sebagai pembenaran.

Ideologi dalam pengertian ini dipakai terutama oleh kalangan psikologi yang melihat ideologi sebagai seperangkat sikap yang dibentuk dan diorganisasikan dalam bentuk yang koheren. Sebagai contoh, seseorang mungkin mempunyai seperangkat sikap tertentu mengenai demonstrasi buruh. Ia percaya bahwa buruh yang berdemonstarsi mengganggu kelangsungan produksi. Akibatnya, perusahaan tidak bisa memproduksi barang dan mengalami kerugian besar yang akibatnya juga akan diderita oleh buruh itu sendiri. Karena itu, demonstrasi buruh tidak boleh ada sebab hanya akan menyusahkan orang lain. Jika kita bisa memprediksikan sikap seseorang semacam itu, kita dapat mengatakan bahwa seseorang mempunyai ideologi kapitalis atau borjuis. Meskipun ideologi di sini terlihat sebagai sikap seseorang, tetapi ideologi di sini tidak dipahami sebagai sesuatu yang ada dalam diri individu itu sendiri, malinkan diterima dari masyarakat. Ideologi bukan sistem unik yang dibentuk oleh pengalaman seseorang, tetapi ditentukan oleh masyarakat di mana ia hidup, posisi sosial dia, pembagian kerja, dan lain sebagainya.

Kedua, sebuah sistem kepercayaan yang dibuat ide palsu atau kesadaran palsu- yang bisa dilawankan dengan pengetahuan ilmiah. Ideologi dalam pengertian ini adalah seperangkat kategori yang dibuat dan kesadaran palsu di mana kelompok yang berkuasa atau dominan 
menggunakannya untuk mendominasi kelompok lain yang tidak dominan. Karena kelompok yang dominan mengontrol kelompok lain dengan menggunakan perangkat ideologi yang disebarkan ke dalam masyarakat, akan membuat kelompok yang didominasi melihat hubungan itu tampak natural dan diterima sebagai kebenaran. Di sini, ideologi disebarkan lewat berbagai instrument dari pendidikan, politik sampai media massa. Sebagai contoh, pada masa kekuasaan Soeharto, media massa diposisikan secara sistematis sebagai aparatus ideologis negara. Posisinya memang di luar kekuasaan, namun fungsinya adalah untuk menciptakan kesadaran palsu bagi masyarakat agar kepentingankepentingan negara (penguasa) bisa berjalan. Melalui media, mereka mengenal dengan akrab nyaris tanpa upaya kritis- antara lain kata-kata pembangunan, bapak pembangunan, lepas landas, stabilitas nasional, musyawarah mufakat, demokrasi pancasila, budaya laten komunis (Sobur, 2004:66). Jadi, Ideologi di sini bekerja dengan membuat hubungan-hubungan sosial tampak nyata, wajar, dan alamiah, dan tanpa sadar kita menerima sebagai kebenaran.

Ketiga, proses umum produksi makna dan ide. Ideologi di sini adalah istilah yang digunakan untuk menggambarkan produksi makna. Berita demonstarsi buruh pabrik rokok Gudang Garam secara umum menggambarkan apa yang dilakukan oleh buruh dan bagaimana dampaknya terhadap produksi perusahaan, perekonomian masyarakat, dan pemerintah. Yang ditekankan dalam berita di sini bukan betapa kecilnya gaji yang diterima oleh buruh, tetapi sikap buruh pabrik yang merugikan banyak pihak. Berita secara tidak sengaja membuat pembalikan/oposisi bahwa buruh anarkis, perusahaan bagus. Perusahaan berperan dalam perekonomian daerah dan nasional, sementara buruh menciptakan kekacauan. Dari sini, diketahui bahwa ideologi bekerja dalam memproduksi makna dapat dilihat dari bagaimana tindakan masyarakat dan pengusaha itu digambarkan dan bagaimana posisi kelompok yang terlibat diposisikan (Eriyanto, 2001:87-92).

Dalam ilmu-ilmu sosial, ideologi dibagi dalam dua kategori, yaitu; ideologi secara fungsional dan secara struktural. Ideologi secara fungsional diartikan sebagai seperangkat gagasan tentang kebaikan bersama; atau tentang masyarakat dan negara yang dianggap paling baik, sedangkan ideologi secara struktural diartikan sebagai sistem pembenaran, seperti gagasan dan formula politik atas setiap kebijakan dan tindakan yang diambil oleh penguasa. Menurut pendekatan struktural, konflik kelas yang memiliki sarana produksi materiil dengan sendirinya memiliki sarana produksi mental, seperti gagasan, budaya dan hukum. Gagasan kelas yang berkuasa di manapun dan kapanpun merupakan gagasan yang dominan. Gagasan, budaya, hukum dan sebagainya sadar atau tidak merupakan pembenaran atas kepentingan materiil pihak yang memiliki gagasan yang dominan. Sistem pembenaran ini disebut ideologi.

Dewasa ini, menurut Jorge Larrain, istilah ideologi dapat dipahami dalam dua pengertian yang bertolak belakang. Secara positif, ideologi dipersepsi sebagai suatu pandangan dunia (worldview) yang menyatakan nilai-nilai kelompok sosial tertentu untuk membela dan memajukan kepentingan-kepentingan mereka. Sedangkan secara negatif, ideologi dilihat sebagai kesadaran palsu, yaitu suatu kebutuhan untuk melakukan penipuan dengan cara memutarbalikkan pemahaman orang mengenai realitas (Sobur, 2004:61).

Selain beberapa pengertian di atas, masih banyak pendapat lain yang mengemukakan pengertian ideologi dengan versinya sendiri-sendiri. Namun demikian, pada hakekatnya semua pengertian itu dapat dikembalikan pada salah satu dari dua makna, yaitu (1) ideologi dalam arti positif, dan (2) ideologi dalam arti negatif.

\section{Hakekat dan Fungsi Bahasa}

Bahasa merupakan sistem kode atau lambang yang dibuat atau dipergunakan oleh anggota masyarakat secara bersama-sama berdasarkan kesepakatan dalam bentuk tuturan (Rahardjo, 2002:50). Bahasa disebut kode atau lambang karena berupa rangkaian bunyi yang dihasilkan oleh alat ucap manusia yang diberi makna tertentu. Kode atau lambang adalah kesatuan dari suatu bunyi dengan sebuah makna atau ide yang terkandung dalam bunyi. Ini berarti bahasa adalah sesuatu yang terdiri dari bunyi. Bunyi itu bertindak sebagai lambang, yang melambang sesuatu, yaitu makna. Jika ada pertanyaan filosofis, "mengapa suatu obyek dinamakan air, mengapa tidak dinamakan tanah atau langit? Maka jawabanya kira-kira begini, penamaan itu hanyalah konvensi (kesepakatan) warga pemakai bahasa itu. Masyarakat bersepakat dan secara sewenang-wenang menentukan nama air untuk obyek itu, bukan ira atau ari, apalagi tanah atau langit. Bahwa air itu disusun dari bunyi-bunyi $/ a /+/ i /+/ r /$, dan bahwa susunan bunyi itu bermakna ini atau itu, juga bergantung pada konvensi tadi (Djojosoeroto, 2007:50).

Dalam wacana linguistik, bahasa diartikan sebagai sistem simbol bunyi bermakna dan berartikulasi (dihasilkan oleh alat ucap), yang 
bersifat arbirter dan konvensional, yang dipakai sebagai alat komunikasi oleh sekelompok manusia untuk melahirkan perasaan. Yang dimaksud arbitrer (manasuka) di sini adalah tidak adanya hubungan wajib antara lambang bahasa (yang berwujud bunyi itu) dengan konsep atau pengertian yang dimaksud oleh lambang tersebut (Chaer, 2003:45). Hal ini akan lebih jelas bagi orang yang mengetahui lebih dari satu bahasa. Misalnya untuk menyatakan binatang yang disebut equus caballus, orang inggris menyebutnya horse, orang Prancis cheval, orang Indonesia kuda, dan orang Arab hison. Semua kata ini sama tepatnya, sama arbirternya. Semuanya adalah konvensi sosial, yakni sejenis persetujuan yang tidak diucapkan atau kesepakatan secara diam-diam antara sesama anggota masyarakat yang memberi setiap kata makna tertentu (Djojosoeroto, 2007:89).

Ferdinand de Saussure dalam dikotominya membedakan apa yang disebut signifiant (lambang bunyi atau penanda) dan signifie (petanda atau konsep yang dikandungnya). Menurutnya, hubungan antara keduanya itulah yang disebut bersifat arbitrer, sewenang-wenang atau tidak ada hubungan wajib di antara keduanya. Lambang yang berupa bunyi tidak memberi saran atau petunjuk apapun untuk mengenal konsep yang diwakilinya. Tidak adanya hubungan antara keduanya itu menyebabkan Bolinger mengatakan seandainya ada hubungan antara lambang dengan yang dilambangkannya itu, maka seseorang yang tidak tahu suatu bahasa tertentu akan dapat menebak sebuah kata apabila dia mendengar kata itu diucapkan. Kenyataannya, kita tidak bisa menebak makna sebuah kata dari bahasa apapun (termasuk bahasa sendiri) yang belum kita dengar, karena bunyi kata tersebut tidak memberi saran atau petunjuk apapun untuk mengetahui maknanya (Chaer, 2003:46).

Bahasa sebagai lambang bunyi digunakan sebagai alat komunikasi dan interaksi oleh setiap manusia dalam hidupnya. Ia adalah satu-satunya alat komunikasi manusia yang paling baik dan paling sempurna dibandingkan dengan alat komunikasi yang lainnya. Hal ini tentu karena bahasa dapat gunakan untuk berkomunikasi dalam berbagai situasi dan kondisi, meskipun dalam keadaan gelap. Bahkan, dengan bantuan alat-alat modern dewasa ini, sistem komunikasi bahasa dapat menembus setiap ruang dan waktu (Chaer, 1995:29-30).

Secara genetis, bahasa hanya ada pada manusia, tidak terdapat pada makhluk hidup lainnya seperti binatang. Alat komunikasi pada binatang bersifat instinktif sehingga proses komunikasi pada setiap jenis binatang semuanya sama. Seekor simpanse menyatakan rasa senang dengan memukul-mukul dadanya dengan kepalan tangan. Lebah melakukan putaran sambil terbang beberapa kali untuk mengomunikasikan bahwa pada jarak tertentu terdapat madu. Komunikasi binatang dilakukan dengan bunyibunyi dan isyarat tubuh yang sama pada setiap jenis binatang (Chaer, 1995:32-33). Jadi, berbeda dengan binatang, manusia berkomunikasi dengan menggunakan bahasa, isyarat, dan tanda. Kedua alat komunikasi terakhir digunakan oleh binatang tetapi bahasa tidak. Jadi, bahasa sebagai alat komunikasi hanya digunakan oleh manusia. Sejalan dengan pemilikan bahasa oleh manusia, pikiran dari satu pihak dan budaya dari pihak lain juga milik manusia dan tidak terdapat pada binatang.

Sebagai alat komunikasi, bahasa digunakan manusia untuk menyampaikan pikiran, gagasan, konsep, atau juga perasaan pada yang lainnya, baik secara lisan maupun tulisan. Bahasa adalah alat utama untuk mengkomunikasikan isi fikiran. Dengan bahasa, manusia mampu melakukan tiga hal yang sangat esensial dalam hidupnya. Pertama, pada tataran paling sederhana dengan bahasa manusia mampu berkomunikasi dengan sesamanya. Kedua, bahasa merupakan landasan utama pada mana gambaran mental internal manusia ditata dalam proses yang disebut berpikir. Ketiga, bahasa memungkinakan manusia terlibat dalam proses interaksi sosial, perubahan sosial dan pembentukan arah cita-cita perubahan sosial budaya. Karena itu bahasa tidak hanya dibentuk dan ditentukan tetapi sebaliknya juga mampu membentuk dan menentukan sejarah sosial (Tamba, : 2008).

Sedangkan menurut Russell, bahasa mempunyai tiga fungsi/tujuan, yaitu: (1) Untuk mengindikasikan atau menyatakan fakta. (2) Untuk mengungkapkan keadaan subjek yang berbicara. (3) Untuk mengubah/mempengaruhi keadaan pendengar. Fungsi bahasa yang pertama inilah yang menjadi problem filosofis baginya. Apa yang membuat kalimat bersignifikansi dan bermakna adalah kapasitasnya mengungkapkan suatu keyakinan dan menunjukkan suatu fakta. Fakta ditunjuk melalui keyakinan dan keyakinan diekspresikan lewat makna dari kata-kata (Cohen, 2007:113-114).

Berdasarkan fungsi-fungsi bahasa tersebut, para ahli bahasa menyimpulkan bahwa fungsi bahasa sebagai alat komunikasi dapat dikelompokkan ke dalam beberapa fungsi. Roman Jakobson, misalnya, mengatakan bahwa fungsi komunikasi bahasa terbagi menjadi enam, yaitu; (1) fungsi emotif, yaitu ujaran berfungsi psikologis, untuk 
menyatakan perasaan, sikap, dan emosi penutur, (2) fatik, yaitu ujaran berfungsi memelihara sosial dan berlaku pada suasana tertentu, seperti halo, apa kabar, ke mana saja, dst, (3) kognitif, yaitu ujaran yang mengacu pada dunia yang sesungguhnya yang sering diberi istilah denotatif dan informatif, (4) referensial, yaitu ujaran berfungsi mempengaruhi dan mengkondisikan pikiran dan tingkah laku para komunikan, (5)metalingual, yaitu ujaran yang berfungsi untuk membicarakan bahasa. Ini adalah ujaran yang paling abstrak karena dipakai dalam membicarakan kode komunikasi, (6) puitis,yaitu ujaran yang dipakai dalam bentuk tersendiri dengan mengistimewakan nilai-nilai estetikanya. Dengan beberapa fungsi inilah, maka dapat dikatakan bahwa dengan bahasalah manusia berkata benar, berkata dusta, menfitnah, setia, mengembangkan ilmu pengetahuan, beramal sholeh, dan sebagainya (Mubarok , 2007:95).

\section{Relasi Bahasa dan Ideologi}

Bahasa dan ideologi memiliki hubungan yang erat, dan keduanya merupakan satu kesatuan yang tak terpisahkan. Dikatakan demikian, karena hampir bisa dipastikan bahwa setiap penggunaan bahasa oleh manusia selalu bersifat ideologis. Bahkan, oleh para linguis kritis, seperti Foucault, Hodge, Van Dijk, dan lainnya, memandang bahwa bahasa adalah ideologi. Ideologi membentuk dan dibentuk bahasa. Dengan ideologi orang memberi makna pada realitas sosial, dan untuk memudahkan penyimpanan, pemeliharaan, pengolahan makna tersebut diperlukan bahasa (Rakhmat, 1996:50).

Dalam pandangan teoritis kritis, bahasa menjadi ciri terpenting bagi bekerjanya sebuah ideologi. Ideologi bergerak melalui bahasa, sehingga apa yang nampak dari struktur bahasa diandaikan sebagai struktur dari masyarakat yang mewadahi sebuah ideologi tertentu. Sebagai contoh, pendapat Althusser yang menyatakan bahwa ideologi tampil dalam struktur masyarakat dan timbul dalam praktik nyata yang dilakukan oleh beragam institusi dalam masyarakat. Menurutnya, esensi ideologi itu dapat ditengarai melalui struktur bahasa. Ideologi bermain di belakang penetapan representasi. Pemaknaan ideologis dimulai dengan memahami bagaimana bekerjanya sistem bahasa dalam struktur sosial. Kombinasi dan disposisi menjadi kata-kata kunci untuk mengurai sejauh mana ideologi bermain dalam bahasa, sehingga untuk membongkar bahasa ideologis maka sebuah representasi harus dibongkar terlebih dahulu strukturnya, kemudian makna dipertalikan dengan keberadaan struktur sosial yang melandasi penggunaan struktur bahasa (prinsip intertekstualitas) (Anang
Hermawan : 2008). Karena itu, mempelajari ideologi dalam beberapa hal dan cara berarti mempelajari bahasa dalam kehidupan sosial. Dalam hal ini, mempelajari cara-cara di mana bahasa digunakan dalam kehidupan sehari-hari, dari pertemuan sahabat dengan anggota keluarga sampai forum-forum dalam debat politik. Ini berarti pula mempelajari cara-cara di mana beragam pengguna bahasa membaurkan dengan kekuasaan, memberi energi, menopang, dan bertindak dengan bahasa (Thompson, 1984:15).

Ideologi, menurut Hafiz Siroj, bekerja melalui bahasa. Karenanya, mempelajari ideologi berarti mempelajari cara-cara dimana makna (pemberian makna) secara terus menerus menjalankan relasi dominasi. Bahasa adalah tanda, dan untuk menemukan ideologi perlu diketahui konteks di mana tanda (bahasa) itu berada dan menurut budaya si pemakai. Sebab, sebuah tanda dapat berubah-ubah maknanya sesuai dengan konteksnya, baik dalam bentuk kalimat, waktu, tempat, maupun budaya. Karena itu, upaya mengeksplorasi interelasi antara bahasa dan ideologi, menurut Thompson (1984:15), berarti menolak analisa terhadap bentuk-bentuk kalimat yang mapan atau sistem tanda dengan menfokuskan pada sebuah medium yang disitu sejarah diproduksi dan kehidupan sosial dikembangkan. Teori ideologi mengajak kita melihat bahwa bahasa bukan sekedar struktur yang dapat digunakan untuk komunikasi dan pertunjukan. Tetapi sebagai fenomena sejarah sosial yang melibatkan konflik manusia. Di sini, bahasa dapat menjadi sumber dari segala kerusuhan dan kekerasan yang terjadi, baik dalam kancah nasional maupun dalam internasional. Dengan menggunkan bahasa yang cukup ringan orang mampu menjustifiksi seseorang dengan tanpa sebuah pertimbangan yang akhirnya mengakibatkan sebuah pemasalahan yang cukup serius kemudian timbullah perang.

Menurut Pecheux, relasi bahasa dan ideologi bertemu pada pemakaian bahasa dan materialisasi bahasa pada ideologi. Keduannya, kata yang digunakan dan makna dari kata-kata menunjukkan posisi seseorang dalam kelas tertentu. Bahasa menjadi medan pertarungan berbagai kelompok dan kelas tertentu yang berusaha menanamkan keyakinan dan pemahamannya. Lebih lanjut, dengan mengutip Althusser, Pecheux menekankan bagaimana seseorang ditempatkan secara imajiner dalam posisi tertentu, atau dalam formasi diskursif seseorang ditempatkan dalam keseluruhan praktik dominasi dalam masyarakat (Eriyanto, 2001:16). 
Relasi bahasa dan ideologi ini tampak pada bagaimana bahasa digunakan tidak hanya sekedar sebagai alat komunikasi, tetapi lebih dari itu bahasa digunakan sebagai alat untuk mempengaruhi, merubah, bahkan untuk menguasai orang lain, sehingga pendengarnya atau pembacanya dapat menerima dan membenarkan semua pesan, ide, gagasan, dan pikiran yang disampaikannya, bahkan kalau bisa harus meyakini dan mengikutinya. Jadi, seseorang pada saat menggunakan bahasa memiliki tujuan tertentu, yaitu ingin dipahami oleh orang lain. Ia ingin menyampaikan gagasan yang dapat diterima oleh orang lain. Ia ingin membuat orang lain yakin terhadap ide dan pikirannya. Ia ingin mempengaruhi dan menguasai orang lain. Lebih jauh lagi, ia ingin orang lain membeli hasil pemikirannya. Jadi, dalam hal ini pembaca atau pendengar atau khalayak sasaran menjadi perhatian utamanya.

Sejalan dengan ini, R. Okta Kurniawan (2003) mengatakan, melalui bahasa, manusia menyatakan identitas dan pengertiannya terhadap lingkungan serta menggunakannya sebagai alat pengolahan masalah dalam mengambil keputusan dan untuk mempengaruhi orang lain. Sebagai contoh bahwa sebuah rencana disampaikan, biasanya dibumbui, dengan perkataan yang lemah lembut, mulut manis yang berbisa dan rayuan yang menggoyahkan keimanan, sehingga pendengar/pembaca terpedaya dibuatnya dan akan membuat keputusan atau mengambil tindakan sesuai dengan yang diharapkannya.

Dalam realitas modern, memang bahasa telah berubah fungsinya menjadi sebuah alat yang paling efektif untuk merubah, menggerakkan, mempengaruhi, dan menguasai. Bahasa ibarat sebuah remote control, yang digunakan sebagai alat penggerak dari jauh bagi individu yang ratusan ribu jumlahnya. Dengan bahasa, menurut Jalaluddin Rahmat, manusia dapat mengatur prilaku orang lain (Sobur, 2006:272). Dengan teriakan bapak, seorang anak kecil dapat menggerakkan lelaki besar diseberang jalan untuk mendekatinya. Dengan aba-aba "maju jalan" seorang sersan dapat menggerakkan puluhan tentara menghentakkan kakiknya dan berjalan dengan tegap. Inilah kekuatan bahasa, kekuatan kata-kata, the power of words.

Kemudian dalam kaitannya dengan realitas politik suatu bangsa, bahasa tidaklah sematamata dijadikan oleh penguasa sebagai alat untuk berkomunikasi dan menyampaikan ide, gagasan, dan kebijakannya pada rakyatnya, tetapi lebih dari itu bahasa dijadikan sebagai alat untuk melegitimasi kekuasaan dan mempertahankan status quonya. Melalui bahasa, penguasa berupaya mencari dukungan dan simpati dari rakyatnya dengan menebarkan pesona dan citra positif yang ada pada dirinya. Dan melalui bahasa pula, penguasa juga berupaya memberangus lawan-lawan politiknya atau pihak-pihak yang berseberangan dengannya, dengan menganggapnya sebagai kelompok oposan, pembangkang, subversive, inkonstitusional, dan lain sebagainya. Hal ini sebagaimana yang dilakukan oleh penguasa pada masa orde baru, ia menuduh lawan-lawan politiknya atau pihak-pihak yang berseberangan dengannya sebagai kelompok subversif, komunis, ekstrim kiri, ekstrim kanan, atau dengan berbagai sebutan lainnya, dengan tujuan untuk menyingkirkan mereka, baik secara politik mupun sosial, sehingga ia mampu mempertahankan kekuasaannya secara utuh.

Secara historis, penggunaan bahasa dalam realitas politik tersebut telah lama diakui dan diyakini oleh berbagai kalangan. Bahkan sejak abad ke-5, orang Athena (Yunani) telah menganggap bahasa sebagai instrumen untuk mencapai tujuan tertentu yang konkret dan praktis. Bahasa dianggap sebagai senjata ampuh dalam percaturan politik tingkat tinggi. Bahasa juga hadir bersamaan dengan sejarah sosial komunitas-komunitas yang dalam pengertian modern disebut sebagai bangsa.

Menurut Ari MP Tamba (2008), bahasa menjadi ruang tafsir yang terbuka yang paling tidak membawa tiga asumsi baru dalam kaitannya dengan dalam realitas politik. Pertama, bahasa senantiasa ditandai oleh ketidastabilan dan ketidaktetapan makna. Kefanaan ini terjadi karena dengan sendirinya bahasa menjadi medan terbuka untuk dimaknai sekaligus kotak terbuka untuk dimasuki berbagai "atribut" di luar bahasa seperti fenomena, kepentingan, atau kehendak yang bisa jadi sangat intersubyektif. Medan terbuka ini pada satu titik dapat saling bertabrakan satu dengan yang lain. Kedua, ketidakstabilan dan ketidaktetapan itu menyebabkan tidak ada metode analisis yang memiliki klaim istimewa apapun atas otoritas dalam kaitannya dengan tafsir bahasa dan tafsir tekstual. Ketiga, dengan posisi bahasa yang penuh dengan ketidakstabilan dan ketakmapanan tafsir merupakan kegiatan yang tidak terbatas.

Dengan demikian, jelas bahwa bahasa memiliki hubungan yang erat dengan ideologi. Bahasa digunakan oleh pemakainya dengan maksud dan tujuan tertentu, khususnya untuk mendominasi pada para pendengarnya.

\section{Penutup}


Bahasa merupakan sistem kode atau lambang yang bersifat arbirter, yang digunakan oleh anggota masyarakat secara bersama-sama berdasarkan kesepakatan dalam bentuk tuturan. Bahasa pada awalnya berfungsi sebagai alat komunikasi sekaligus alat untuk mengungkapkan ide, gagasan, pikiran, dan perasaan seseorang. Dalam perkembangannya, penggunaan bahasa memiliki hubungan yang erat dengan suatu ideologi. Hubungan keduanya bertemu pada pemakaian bahasa dan materialisasi bahasa pada ideologi. Keduanya, baik kata-kata yang digunakan maupun makna dari kata-kata tersebut menunjukkan posisi seseorang dalam kelas tertentu. Bahasa menjadi medan pertarungan berbagai kelompok dan kelas tertentu yang berusaha menanamkan keyakinan dan pemahamannya. Selain itu, hubungan bahasa dan ideologi juga tampak pada bagaimana bahasa digunakan tidak hanya sekedar sebagai alat komunikasi, tetapi lebih dari itu bahasa dipakai sebagai alat untuk mempengaruhi, merubah dan bahkan untuk menguasai orang lain, sehingga pendengarnya atau pembacanya dapat menerima dan membenarkan semua pesan, ide, gagasan, dan pikiran yang disampaikannya, bahkan kalau bisa harus meyakini dan mengikutinya.

\section{DAFTAR PUSTAKA}

Chaer, Abdul dan Leonie Agustina. 1995. Sosioliguistik: Perkenalan Awal. Jakarta: PT. Rineka Cipta. 2003. Linguistik Umum. Jakarta: PT Rineka Cipta.

Cohen, Christiadi. 2007. Bahasa Menurut Ontologi Realisme Analitis Bertrand Russel. Jurnal Teologi Stulos, 6/1 April.

Djojosoeroto, Kinayati. 2007. Filsafat Bahasa. Yogyakarta: Pustaka Book Publisher.

Eriyanto. 2001. Analisis Wacana : Pengantar Analisis Teks Media. Yogyakarta: LkiS.

Hermawan, Anang. 2008. Mitos dan Bahasa Media: Mengenal Semiotika Roland Barthes. http://www.averroes.or.id . Diakses 24 Juli 2008.

Heryanto, Ariel dkk. 1996. Bahasa dan Kekuasaan : Politik Wacana di Panggung Orde Baru. Bandung: Mizan.

Hidayat, Asep Ahmad. 2006. Filsafat Bahasa : Mengungkap Hakikat Bahasa, Makna, dan Tanda. Bandung: PT Remaja Rosdakarya.

Kurniawan, R. Okta. 2003. Bahasa: Sebuah Kekuatan. http://www.badiklat.dephan.go.id/files.

Mubarok, Ahmad Zaki. 2007. Pendekatan Strukturalisme Linguistik dalam Tafsir al-Qur'an Kontemporer "ala" M. Syahrur. Yogyakarta: elSAQ Press.

Rahardjo, Mudjia. 2002. Relung-Relung Bahasa: Bahasa dalam Wacana Politik Indonesia Kontemporer. Yogyakarta: Aditya Media.

Siroj, Hafidz. Tanpa tahun. Konstruksi Ideologi Muhamamdiyah (Studi Wacana Pemikiran Amien Rais dan Syafii Maarif). http://www.digilib.ui.edu

Sobur, Alex. 2004. Analisis Teks Media: Suatu Pengantar Untuk Analisis Wacana, Analisis Semiotik, dan Analisis Framing. Bandung: PT Remaja Rosdakarya.

2006. Semiotika Komunikasi. Bandung: PT Remaja Rosdakarya.

Subagyo, P. Ari. 2008. Ideologi Bahasa Indonesia. Kompas, Rabu, 29 Oktober.

Tamba, Arie MP. 2008. Bahasa antara Tafsir, Fenomena Sosial, dan Kekuasaan, http//jurnalnasional.com/20 Januari 2008.

Thompson, Jhon B. 1984. Analisis Ideologi: Kritik Wacana Ideologi-Ideologi Dunia. Terjemahan: Haqqul Yaqin. Jogjakarta: IRCISoD. 